\title{
The Neolithic Burial of a Child from the Krasnoyarsk Region
}

\author{
Pavel V. Mandryka*a, Olga. E. Poshekhonovab, \\ Kseniia V. Biryulevaa, Liliiia A. Maksimovicha, \\ Anastasiia V. Sleptsovab and Dmitry A. Guruleva \\ a Siberian Federal University \\ Krasnoyarsk, Russian Federation \\ ${ }^{b}$ Tyumen Scientific Centre of the SB RAS \\ Institute of the problems of Northern development \\ Tyumen, Russian Federation
}

Received 10.10.2019, received in revised form 22.01.2020, accepted 18.03.2020

\begin{abstract}
The article analyzes the findings on the Neolithic burial discovered at the Udachny-14 burial site in the city of Krasnoyarsk. The skeleton of a child of 9-10 years old was located head to the south-west parallel to the river (upstream). Over the grave there is a hearth in which the red deer calcaneal bone is found. Between the skull and the pelvis bones, two beaver incisors lying parallel to each other, could relate to clothing or to decoration. A piece of ochre was found near the left instep bones. Almost all the bones of the legs of the buried individual were in anatomical order and were elongated along the long burial axis. The corpus bones, shoulder girdle and head were greatly displaced. Such order of the bones suggests that the grave was disturbed a short time after the funeral. Odontologic examination of the remains shows a combination in the dentition structure of the "eastern" and "western" signs with a predominance of the first ones. The greatest odontologic similarity of the buried individual is related to a few Neolithic series from the Northern Angara region, which partially correlates with the archaeological data. Based on the ${ }^{14} \mathrm{C}$ date and the stratigraphic position, the burial is dated to the late Neolithic (the end of the $4^{\text {th }}$ millennium $\mathrm{BC}$ ). Among the few sites in the region, it finds analogies in the necropolises of "Bor" urotshistshe at the mouth of the Bazaikha river, near the summer children's camps of the GorONO and in the Gremyachiy Ruchei burial ground. They are characterized by the soil burials, the grave pits located mainly along the river, postmortal manipulations with the dead body, over- or near grave fire, use of jewellery made of teeth and animal bones as accompanying burial objects.
\end{abstract}

Keywords: the Middle Yenisei, the Krasnoyarsk region, Udachniy-14 burial site, the Late Neolitic, anthropologic characteristics, odontologic examination, burial site, postmortal manipulations.

\footnotetext{
(C) Siberian Federal University. All rights reserved

* Corresponding author E-mail address: pmandryka@yandex.ru ORCID: 0000-0002-8647-3823 (Mandryka); 0000-0002-6992-3183 (Gurulev); 0000-0003-2593-7775 (Biryuleva); 0000-0002-5081-4331 (Poshekhonova); 0000-0002-7981-161X (Sleptsova); 0000-0002-5499-6996 (Maksimovich)
} 
The work was carried out on a state assignment - projects No.AAAA-A17-117050400143-4.

Research area: archeology.

Citation: Mandryka, P.V., Poshekhonova, O.E., Biryuleva, K.V., Maksimovich, L.A., Sleptsova, A.V., Gurulev, D.A. (2020). The neolithic burial of a child from the Krasnoyarsk Region. J. Sib. Fed. Univ. Humanit. Soc. Sci., 14(1), 69-84. DOI: 10.17516/1997-1370-0571.

\section{Introduction}

The Neolithic era of the Middle Yenisei's studied extremely unevenly. One of the concentration of archaeological sites is located in Krasnoyarsk and its outskirts, known as the Krasnoyarsk archaeological area. It's assumed, not only their accessibility for the researchers, but also the landscape originality was the reason for that - the mountain, piedmont and plain landforms conjoin together; there are also taiga and forest-steppe ecosystems, which, undoubtedly, should have been reflected in the ancient history of this territory.

Currently, the Krasnoyarsk region has about 17 Neolithic burials out of eight burial grounds excavated and studied by the researchers since the end of the $19^{\text {th }}$ century. The issues of their cultural reference and dating have been discussed numerous times. Thus, for the first time, the burials of the "Bor" urotshistshe at the mouth of the Bazaikha river, excavated and studied by I.T. Savenkov (Savenkov, 2001: 89), were dated to the Neolithic period. Later, N.K. Auerbakh pointed to their connection with the Kitoy burial grounds in the upstream water of the Angara (Auerbakh, 1929: 4). This idea was developed by A.P. Okladnikov, who proved the influence of the cultures found in the buried complexes of the Baikal region on the Krasnoyarsk area. In particular, he identified two groups of Neolithic burials - the early group was compared with the Serovo culture, while the latter one was synchronized with the Late Kitoy and the Early Glazkovo complexes (Okladnikov, 1949: 13, 1957: 34-36). Subsequently, L. P. Khlobystin in his summary on the Neolithic of the Middle Yenisei, linked most of the burials (Bazayskaya site, Afontova Gora, from Uzenkaya ulitsa, Gremyachy Ruchei) to the Early Bronze (the second half of the $3^{\text {rd }}$ millennium $\mathrm{BC}$ ) and correlated them to the West Angara pottery types (Khlobystin, 1996: 293-294). By publishing the archival reports on the Neolithic burials excavations on Afontova Gora, N.P. Makarov and A.S. Vdovin justified their earlier dating - the second half of the $5^{\text {th }}-$ early $4^{\text {th }}$ millennium BC (Vdovin, Makarov, 2016).

The abovementioned conflicts are mainly caused by insufficient information about the objects and their absolute dating, as well as the materials for the burials - settlements comparative analysis. Therefore, the discovery of a new burial complex is of particular importance for the study of the Neolithic in the Krasnoyarsk region. This work aims presenting and analyzing materials on the burial of a child excavated by the Archaeological team of Siberian Federal University in 2015 in the Udachny-14 site.

\section{Materials}

The burial was found in excavation site № 2 in the southwestern part of the Udachny-14 area, 50 meters from the current edge of the 8-meter high terrace of the Yenisei. Geographically, the complex is at the border of the Krasnoyarsk forest-steppe and the mountain-taiga offspurs of the Eastern Sayan.

The site belongs to the Monastery complex of archaeological sites and occupies the territory of the active Dormition Monastery, built in the end of the $19^{\text {th }}$ century. Most of the site suffered intensive exploration, reclamation and interception with some construction debris (Titova, Biryuleva, Mandryka, 2017).

The overgrave construction of the soil burial was not found. At the level upper part of the brown sandy loam soil horizon, at $19 \mathrm{~cm}$ depth from the lower boundary of the current man-made layer, overlapping the southwestern half of the grave, a fireplace with a dark lens 


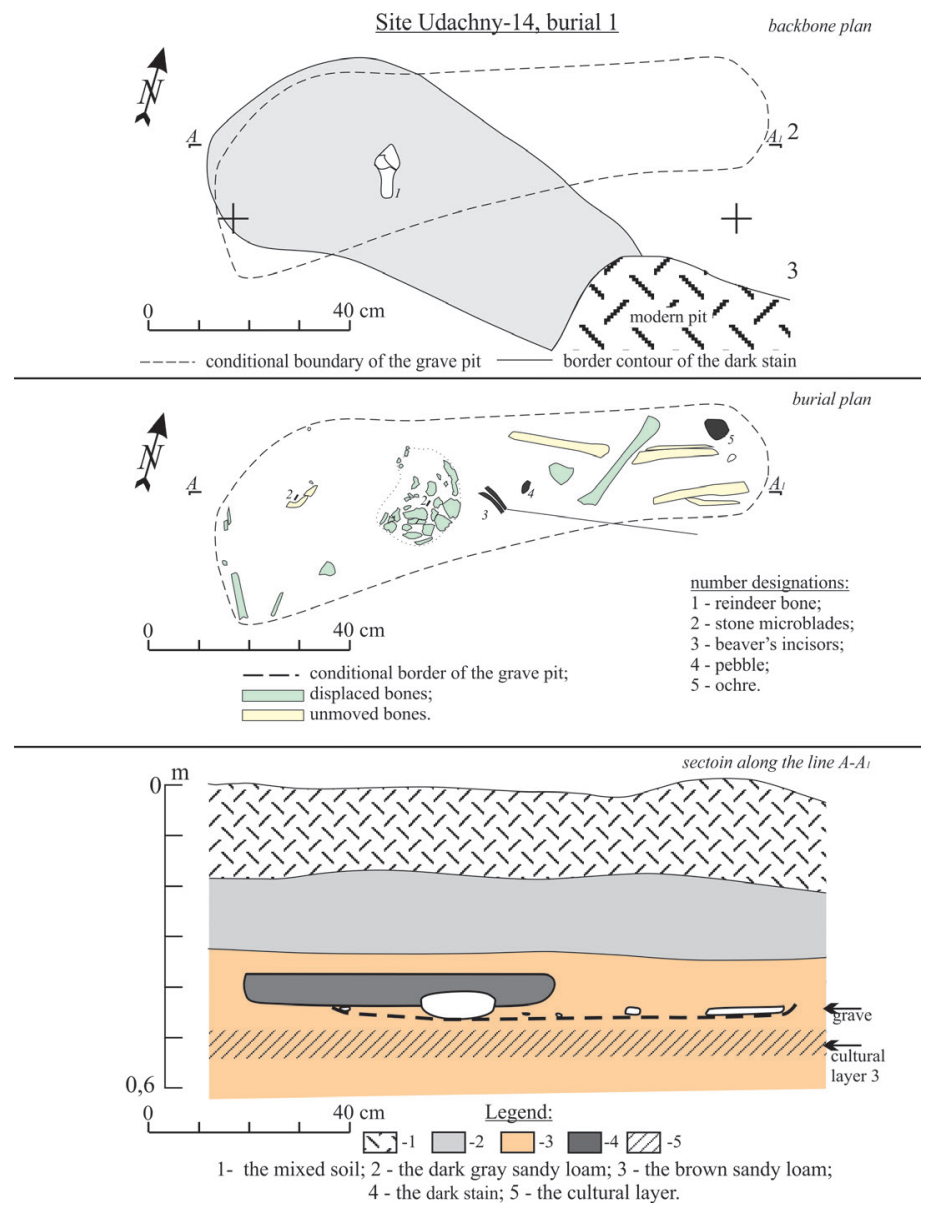

Fig. 1. The plan of the burial from the Udachny-14 site

was found (Fig. 1). The oval shape lens, NWSE elongated with axis, $76 \times 45 \mathrm{~cm}$, consisted of a dark gray sandy loam free of foreign inclusions. It included an uninjured red deer calcaneal bone (Cervus elaphus) ${ }^{1}$ free from fire. A part of the lens in the eastern segment is destroyed by the modern excavations.

Under the hearth in the body of the brown sandy loam, the fragmentary skull, lower jaw, separately lying molar tooth and vertebra (?) alongside with other bones of the postcranial human skeleton, were unearthed. The lower extremities and pelvis were registered at the same line with the skull. The grave pit borders were unreadable and were identified roughly relying

\footnotetext{
1 The definition was proposed by A.M. Klement'ev, Cand. of Scince (Geography), at IEC SB RAS, for which the authors show their deep gratitude.
}

on the skeleton position and darker colour of the sandy loam. The area occupied by the human bones was $112 \times 42 \mathrm{~cm}$. The skeleton lied with the head south-west parallel to the river (upstream) (Fig. 1). Between the skull and pelvic bones two lying parallel beaver incisors and a pebble were lying. A unbroken stone microblade and one fragment lied under the skull and near the lower jaw (Fig. 2), and a piece of ochre was found near the left instep bones.

\section{Anthropological research}

When reconstructing the burial posture, the field materials and observations, relevant literature (Zaitseva, Razhev, 2007; Duday, 2009) and the author's methodology of D.I. Razhev, following the lecture course on "Field anthropology" (not published), were 


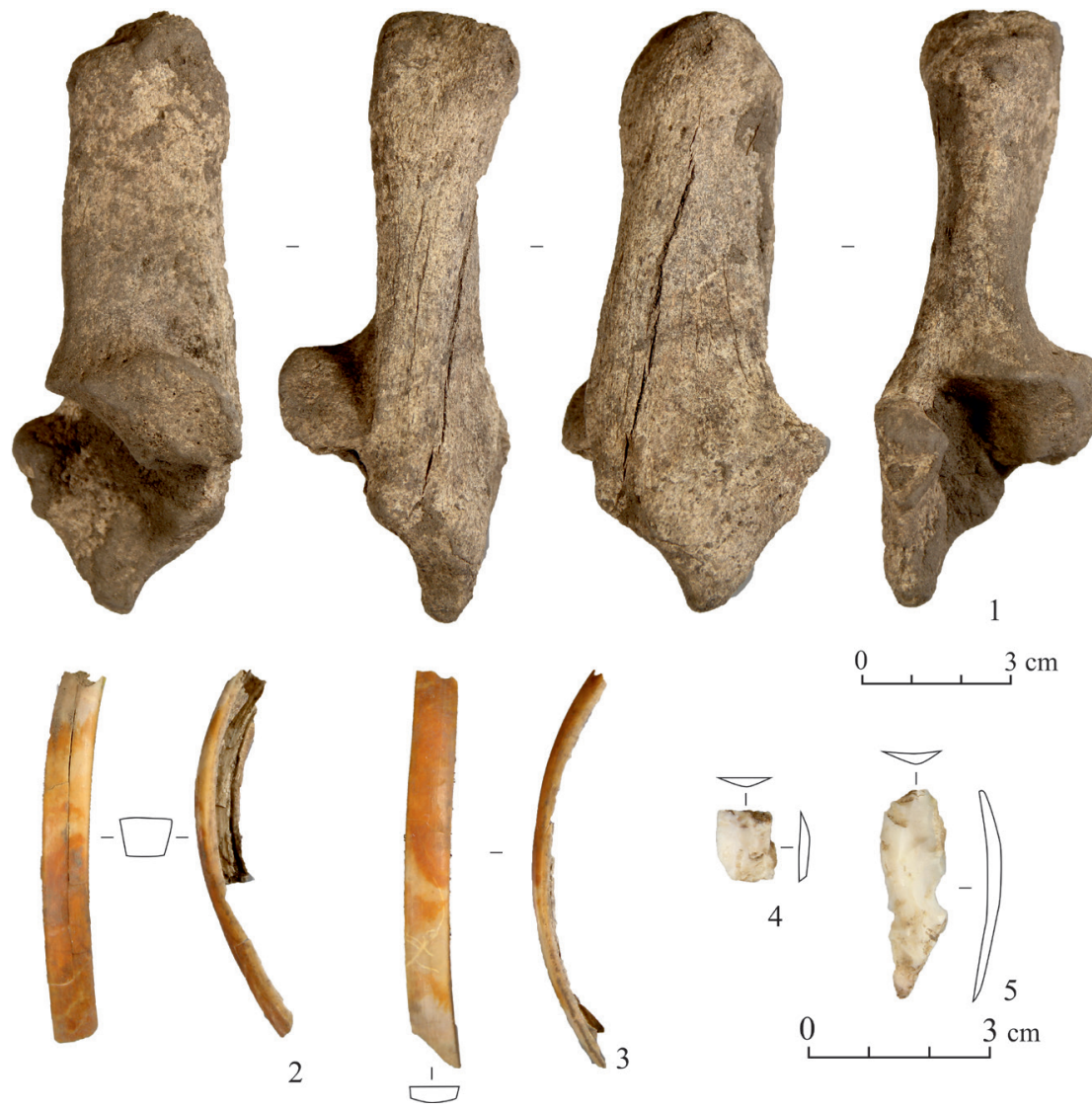

Fig. 2. Accompanying equipment and finds from the grave pit of the burial from the Udachny-14 site: 1 - Red deer calcaneal; 2-3 - Beaver incisors; 4-5 - Stone microblades

used. Visual macro-morphological methods and a set of independent indicator systems were applied to determine the individual's age at the time of death. First of all, the age was identified by the dental formation and eruption (Ubelaker, 1978). When examining the postcranial skeleton, the maturity, basis and glued degree of epiphysis and apophysis were considered (Alekseev, 1966; Bass, 1987). The dental non-metric examination was carried out following the traditional Russian methodology developed by A.A. Zubov (Zubov, 1968; Zubov, 2006), which includes obtaining non-metric and metric features. Moreover, the dental system's archaic features were studies through the recording programme (Zubova, 2013).

Almost all the buried individual's bones of the lower limbs were in the northeastern part of the grave in anatomical order, elongated along the long burial axis. The tibia, left femoral bone, separate left tarsal bones and phalanges were placed in anatomical joint in the back. The right femoral bone was displaced: it was inclined to the burial axis with the distal end to the northeast between the bones of the left leg, on the back surface. The pelvic bones, in the light of a small misalignment, anatomically agreed the right femoral bone. The corpus bones, shoulder girdle and head were displaced. Notably, the skull lied in the center of the burial, on the right side face, and the facial skeleton faced north. The lower jaw rested in the western sector, in the original location of the skull. The bones of the forelimb, scapula and ribs were randomly split around the grave edges.

Basing on the bones order, we can give the following findings on the funeral posture of 
that buried individual: they were laid on their back with legs extended along the burial axis; judging by the distance between the tibia, the legs were not fastened together, i.e. were laid freely. The body, apparently, was also elongated along the grave axis, that is, the lateral or inclination position in regard to the legs was excluded. The position of the hands and head upon the funeral is impossible to identify, since the southwestern part of the grave was disturbed. As the result, the corpus, upper limbs and head were displaced, while the lower jaw remained the same place. The pelvic bones and the right femoral bone were dislocated, but they were most likely joint before. It is known, that the soft tissues that connect the femoral bone and pelvis are corrupted last. It is highly likely that the grave was disturbed a short time after the funeral (Zaitseva and Razhev, 2007; Duday, 2009).

All the damaged bone remains belonged to one individual, judging by the size and growth - a child. The age-at-death, recorded by the dental system analysis, was 9-10 years (Ubelaker, 1978). At this age, the skeleton still continues to grow, new ossification points appear, and already existing bones are gracile and fragile. As it appears from the bones structure of the postcranial skeleton, the age of buried individual is approximately Infantilis II (the scapula coracoid and brachial processes are persistent, there are no synostoses in almost all epiphyses of the long bones and pelvis) (Alekseev, 1966; Bass, 1987); no traces of damage or pathology were found; there were either no enamel hypoplasia lines on the tooth crowns. This proves that in the early childhood the living conditions - food, housing and care - were quite satisfactory. In total, 27 permanent and 8 primary teeth with no caries were documented. There were no crown or enamel breaks as well; dental calculus can be fixed on the lower incisors.

Due to the infancy, there was no option to carry out a craniological examination, though, the well-preserved teeth made it possible to perform a dental non-metric analysis. Among the upper jaw teeth, the right medial and lateral incisors, canine teeth, premolars, primary and permanent molars were available for the research. The right medial incisor was marked with moderate marginal ridges of the lingual surface (score 1), more developed on the lateral incisors (score 2). The finger-shaped ridges were noticed on the first incisor, and developed lingual cusp- on the second ones (score 2). The canine teeth were marked with a poor lingual cusp (score 1) and distal accessory ridges. In the first premolar teeth there was lingual tubercle, smaller than the buccal one (score 1), in the second - a shade less, indeed (score 2). The hypocone of the first and second molars was not reduced (score 4), same as the metacone (score 1). The Carabelli cusp in the first molars was well developed (score 3). The anterior and posterior pits were absent, but there were additional marginal C5 cusp. The average modulus of the upper molars, calculated through the module M1 and M2, was indicated within the microdontia boundaries (Table 1).

The teeth of the lower jaw were represented by permanent incisors, canine teeth, the first right and the second left premolar, permanent and primary molars. The lower incisors had no shovel shape form; a distal accessory ridge was on the canines. The first premolar had a canine-like shape (type 2), the second premolar was molarized and threecusp shape (type 5). This class was marked with distal accessory ridges. The first molars with the "Y"-groove were of 5-cusp shape; the second molars were 4-cusp, with the "X"groove form. Protostylid was absent in the

Table 1. Mesio-distal (MD) and vestibulo-lingual (VL) diameters of crowns of molars (mm)

\begin{tabular}{|c|c|c|c|c|c|c|c|}
\hline \multicolumn{4}{|c|}{ Upper jaw } & \multicolumn{4}{c|}{ Lower jaw } \\
\hline \multicolumn{2}{|c|}{$\mathrm{M}^{1}$} & \multicolumn{2}{|c|}{$\mathrm{M}^{2}$} & \multicolumn{2}{c|}{$\mathrm{M}_{1}$} & \multicolumn{2}{c|}{$\mathrm{M}_{2}$} \\
\hline $\mathrm{MD}$ & $\mathrm{VL}$ & $\mathrm{MD}$ & $\mathrm{VL}$ & $\mathrm{MD}$ & $\mathrm{VL}$ & $\mathrm{MD}$ & $\mathrm{VL}$ \\
\hline 9,97 & 10,13 & 9,35 & 10,64 & 10,66 & 10,02 & 9,52 & 9,44 \\
\hline
\end{tabular}


first molars, but a protostylid pit was fixed in the second ones. Tami (c7), accessory cusp and distal trigonid crest were absent. In the first molars, a deflecting wrinkle was recorded, thus, the second metaconid groove enters the fissure III (2medIII). The average module size of the lower molars set was within the microdontia characteristic (Table 1).

Thus, the dental complex recorded in the buried individual in the Udachny-14 justifies the combination of "eastern" and "western" signs with a predominance of the first ones. Single archaic markers give special originality to the complex.

\section{Discussion}

Relying on the sum of archaeological and anthropological data, the most likely is the following reconstruction of the funeral ceremony. The child corpse was laid in a shallow grave pit, elongated on its back with its head to the southwest (parallel to the river, head upstream). In a short period of time, the grave was disturbed, which is proved by the displacement of the skull and some bones of the postcranial skeleton. The beaver incisors, which could relate to clothing or to jewellery, appeared accidentally or were specially laid. When excavating the grave or filling it, in the burial, there two stone microblades and river pebble appeared, and over the disturbed part of the grave an untouched red deer calcaneal bone was placed over the buried skull. It is likely that the displacement of the bones and their subsequent covering were a part of the ritual or memorial ceremonies.

The burial is dated by the Late Neolithic (the end of the $4^{\text {th }}$ millennium $\mathrm{BC}$ ), as resulted from the absolute ${ }^{14} \mathrm{C}$ dating performed on the buried individual's bone. The obtained AMS date marked the time of death $4570 \pm 58$ (NSKA-1636), which, providing for calibration, gives a $79.5 \%$ probability of the formation of the burial within 3385-3092 years $\mathrm{BC}^{2}$. The stratigraphic context of the burial pit and the skeleton also meet this date. They are recorded above the level of the third cultural layer of the site, where the stone industry and frag-

\footnotetext{
2 OxCal 4.3 programme and IntCal13 calibration scale were
} used there. ments of ceramics of the Ust'-Belaya type are found (Gurulev, Biryuleva, 2018). By analogy to the pottery complexes of the sites of the Krasnoyarsk forest-steppe, this layer is date by the Middle Neolithic (mid - second half of the $4^{\text {th }}$ millennium BC) (Makarov, 2005: 154-156; Timoshchenko, Savel'ev, Bobrov, 2016: 100).

The burial tools do not contradict the Late Neolithic age as well. The beaver incisors, as a part of accompanying funeral equipment, are quite often found in the complexes belonging to the Late Neolithic and the Early Bronze across the vast territories of Siberia (Petrov, 1994: 60; Okladnikov, 1950: 385; Okladnikov, 1976: 58, 209; Privalikhin, Drozdov, Makulov, 2013: 51; Dudarek, Lokhov, Leibova, 2015: 55, etc.). In the Krasnoyarsk region, they were found in a collective burial at the mouth of the Gremyachciy Ruchei and in one of the burials (№ 5 according to Table 2) of the "Bor" urotshitsche (Glusskaia, 1963b; Savenkov, 1886).

To reveal the cultural affiliation of the Udachny-14 burial site, it should be compared by the funeral ceremony with the Neolithic complexes of the Krasnoyarsk region (Table 2) and adjacent territories. In Krasnoyarsk and its outskirts, eight locations of the Neolithic burials are known, all of them are located at different terraces of the Yenisei (Fig. 3). The largest necropolis contains 6 Neolithic graves, in which 7 individuals were buried; it was examined in the "Bor" urotshitsche, 200 meters west of the mouth of the Bazaikha (Savenkov, 1886; 2001; Auerbakh, 1929)3. Three more "simultaneously buried skeletons of the Stone Age" were excavated by V.V. Peredolsky in 1894 "on the right coast of the Yenisei, detached by the Mana and the Esaulovka" (Peredolskii, 1896: 210-211 $)^{4}$.

On Afontova Gora, in the complex of five burials (Vdovin, Makarov, 2016), the four belong to the Neolithic. The first was found by N.K. Auerbach, V.I. Gromov together with M.M. Gerasimov. It turned out to be destroyed - there were only bone and horns items

\footnotetext{
3 Burial № 2 there refers to the Bronze Age judging by the celt finding (Savenkova, Makarov, 2018: 159).

4 Some researchers supposed that these findings were made near Perevoznaya (Okladnikov, 1949: 11) or at the Perevoznaya site (Savenkova, Makarov, 2018: 159).
} 


\begin{tabular}{|c|c|c|c|c|c|c|c|c|c|c|}
\hline sอ!ณน.ıวว & $\infty$ & ' & + & ' & ' & ' & ' & ' & ' & ' \\
\hline иodeə $M$ & 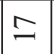 & 1 & - & ' & ' & + & - & ' & ' & $\infty$ \\
\hline SIOOL & $\because$ & ' & $\hat{\wedge}$ & $\begin{array}{r}\sigma \cdot \\
+ \\
+\end{array}$ & 1 & + & $i$ & 1 & $i$ & $\simeq$ \\
\hline . & $\because$ & ' & ' & 1 & ' & 1 & + & ' & ' & + \\
\hline 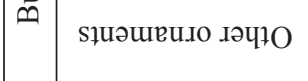 & \pm & ' & ' & ' & ' & + & a. & + & $\stackrel{\infty}{\wedge}$ & $\frac{0}{7}$ \\
\hline S.ıoṣ๐u! .əАвəg & $\cong$ & a & ' & ' & ' & + & ' & ' & ' & N \\
\hline səว:.І7. .ә૫РО & $\simeq$ & + & ' & ' & ' & ' & a. & t & ' & ' \\
\hline 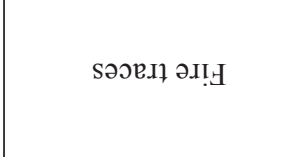 & $=$ & + & $\overbrace{0}^{0}$ & : & : & 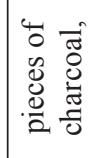 & 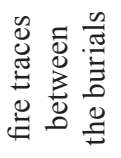 & a. & ' & 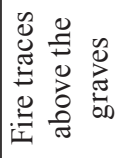 \\
\hline 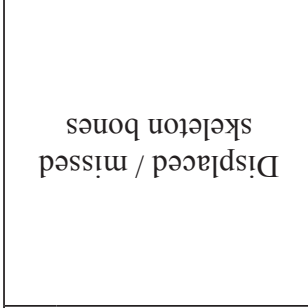 & 인 & 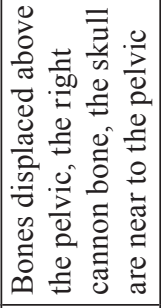 & ' & $\begin{array}{l}\overline{\bar{z}} \\
\frac{\bar{z}}{n} \\
\dot{2}\end{array}$ & 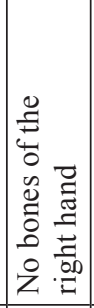 & 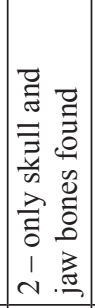 & 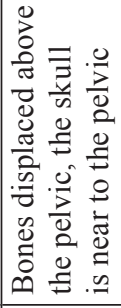 & ' & 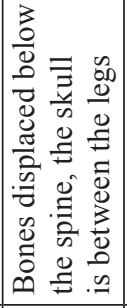 & ' \\
\hline 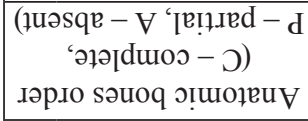 & $a$ & a & U & $a$ & a & 帒 & $a$ & 0 & $a$ & $\ll$ \\
\hline 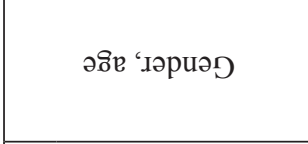 & $\infty$ & छீ官 & a. & a. & r. & 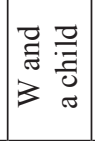 & $\Sigma$ & $\underbrace{\infty}_{3}$ & $\begin{array}{l}n \\
\text { ô } \\
\text { ñ }\end{array}$ & 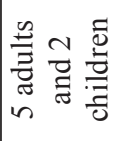 \\
\hline 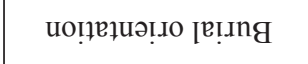 & $r$ & 3 & 3 & 3 & 3 & 3 & 3 & 3 & z & ì \\
\hline 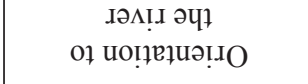 & 0 & $\leftarrow$ & $\longleftarrow$ & $\leftarrow$ & $\leftarrow$ & $\leftarrow$ & $\leftarrow$ & $\leftarrow$ & $\uparrow$ & $=$ \\
\hline 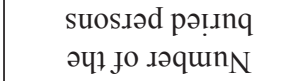 & in & - & - & - & - & a & - & - & - & 当 \\
\hline 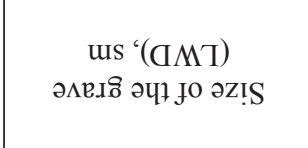 & + & $\begin{array}{l}\stackrel{0}{x} \\
\stackrel{x}{y} \\
\stackrel{y}{x} \\
\stackrel{y}{\Xi}\end{array}$ & a. & a. & a. & 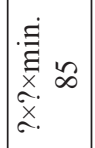 & 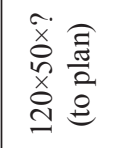 & a. & $\begin{array}{l}\tilde{x} \\
\hat{x} \\
\dot{x} \\
\vec{y}\end{array}$ & 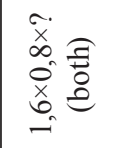 \\
\hline 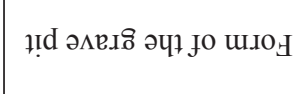 & $m$ & a. & a. & a. & a. & a. & a. & a. & $\bar{\sigma}$ & $\begin{array}{l}\bar{a} \\
\tilde{a} \\
\text { N }\end{array}$ \\
\hline †! әнв.Іоి рәрлооәу & $\sim$ & ' & a. & $\sigma$. & a. & $\curvearrowright$. & a. & a. & + & + \\
\hline 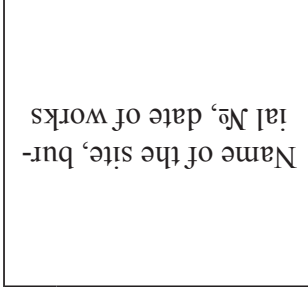 & - & 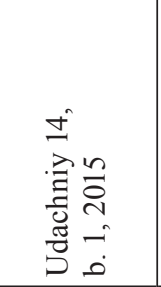 & 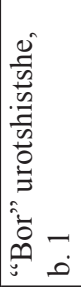 & 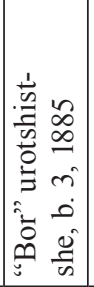 & 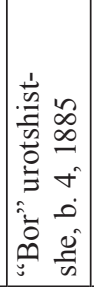 & 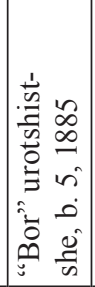 & 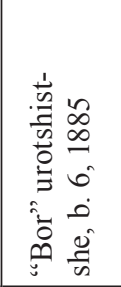 & 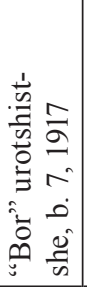 & 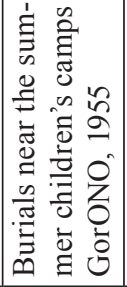 & 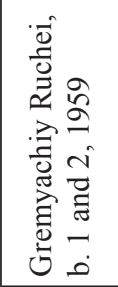 \\
\hline
\end{tabular}




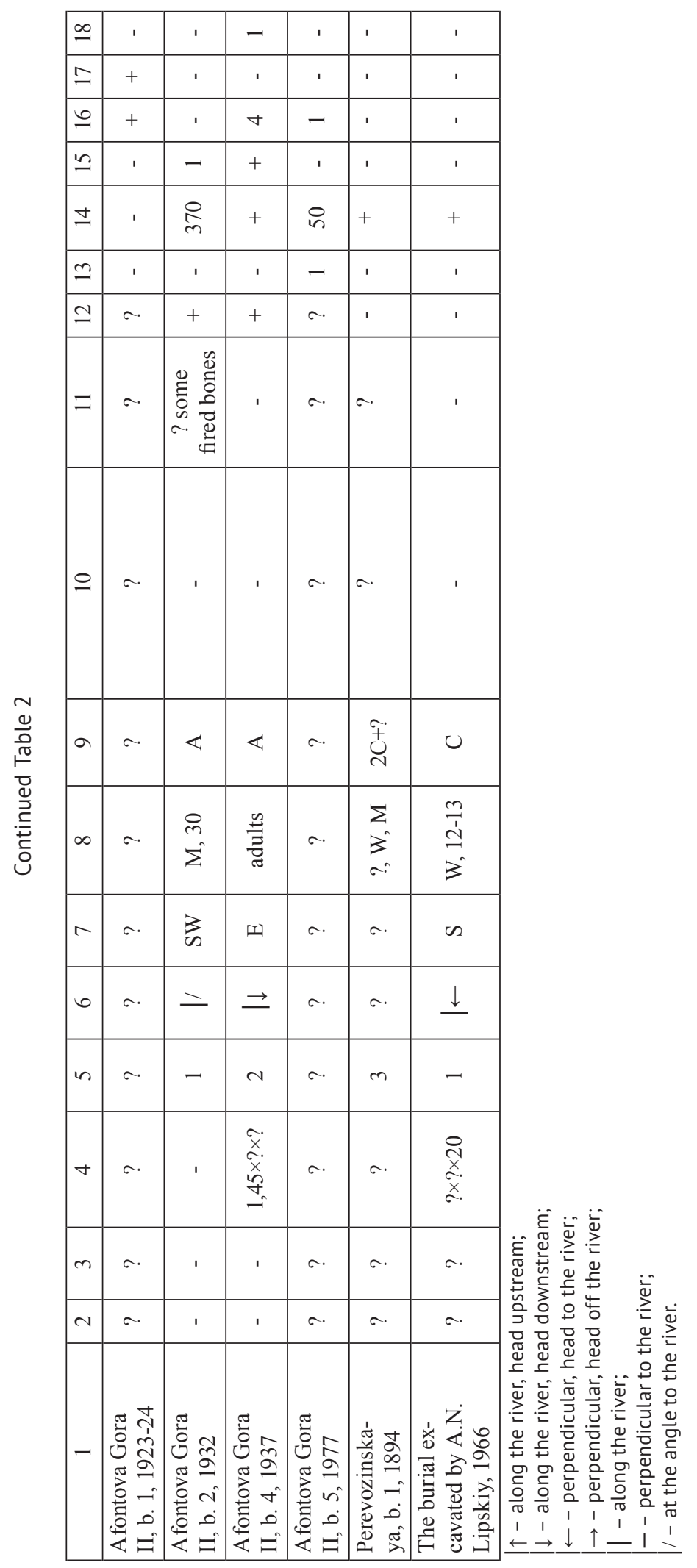




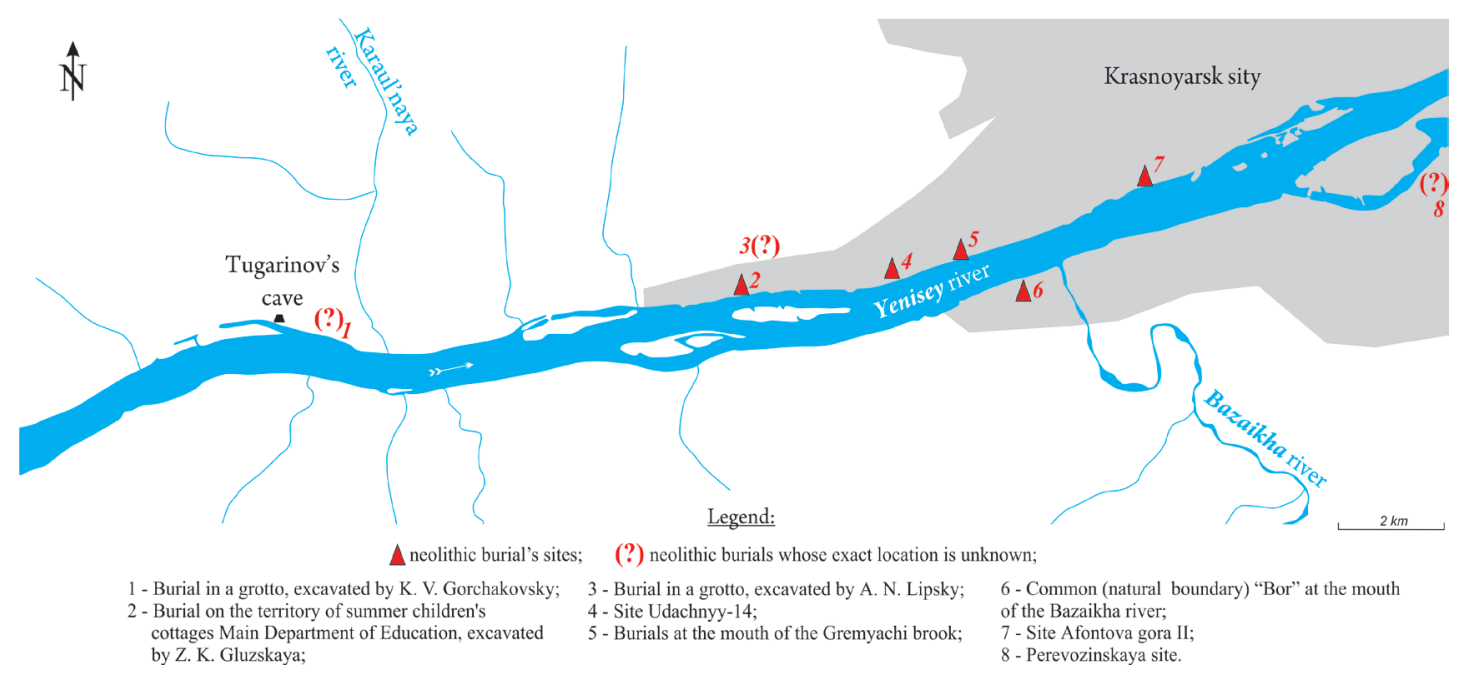

Fig. 3. The map of discovered Neolithic burial grounds in Krasnoyarsk and its outskirts

preserved. The second burial was studied in the "landslide on the hillside" in 1932 by A.F. Katkov and V.G. Kartsov (At al.; Savenkova and Makarov, 2018). The third one was found by A.P. Okladnikov in 1937; it was located three meters from the excavation area of A.F. Katkov (Okladnikov, 1949). The information about the fourth, also destroyed, Neolithic burial on Afontova Gora burial site was brought to the Krasnoyarsk Museum of Local Lore in 1977 (Vdovin, Makarov, 2016).

Some of the bones of at least 7 individuals (five adults and two children) were discovered in 1959 by Z.K. Glusskaya (1963b) in two graves at the mouth of the Gremyachiy Ruchei. In 1955, she excavated another Neolithic burial of a 30-35 years old woman near the summer children's camps of GorONO ${ }^{5}$ (Glusskaia, 1963a). The exact location of another Neolithic burial is unknown. It was opened in 1966 by A.N. Lipsky and was published by V.P. Alekseev (Alekseev, 1983). This is the burial of a girl of 12-13 years old, buried on her back with her head south. As part of the accompanying tools, a shells-made necklace and a red deer tooth pendant were found there. In addition, there are some reports that the burial, presumably of the Neolithic time, was excavated by a local historian K.V. Gorchakovsky, but the data was lost.

\footnotetext{
City Board of Education.
}

All considered burials are similar on a number of common features (Table 2). They are all soil, without stone masonry and overgrave construction. There are more individual burials, two cases are twin graves, and one is, presumably, collective. In all the burials, the bones are placed along the river, head upstream (west and southwest); one with the head downstream (east), two (?) were placed perpendicular to the river (north and south), and one more - at an angle to the river (southwest). In 9 graves, the anatomical order of the skeleton was modified: the bones were displaced, and some of them were missing. Not all such cases were reasoned by the ritual actions, at least four of the graves were complete or partial destroyed by the slope processes. In three cases, the presence funeral fire was evident and in the same number of burials there were ochre remains.

The ritual closest to the funeral from the Udachny-14 are the $5^{\text {th }}$ and $6^{\text {th }}$ burials of the "Bor" urotshitsche at the mouth of the Bazaikh excavated by I.T. Savenkov in 1885' (Savenkov, 1886: 32, 2001: 88-89). They are similar by the bones placed along the east-west ${ }^{7}$ line, by their location parallel

\footnotetext{
6 Since the total numbering of the necropolis burials in the "Bor" has never been calculated anywhere, the sequential numbers assigned in the summary of the attached Table are used in the text.

7 In the description of the burial ground, the author says that all the bones were laid east, however, this contradicts the plan
} 
to the Yenisei watercourse, with their heads upstream, and by the presence of fire remains between these neighbouring graves. In the $6^{\text {th }}$ burial of the "Bor", as well as in the Udachny-14 burial site, the anatomical order of the lower extremities bones was preserved, given the absence and displacement of the upper body bones: the skull lay near the pelvis bones, facing the north. A wide opening was noted on the skull in the temporal region, interpreted by the author as a sign of trepanation (Savenkov, 2001: 88). Near the skeleton, a small assembly with a polisher (?), ground adze, knife, bone dagger with grooves, and zoomorphic bone-made figures were found. A.P. Okladnikov (1957) pointed out the similarity between the equipment from the burials at the mouth of the Bazaikha and the Serovo burials, though, he also said about the differences in the funeral rites.

The funeral ceremony details noted in the Udachny-14 burial are also presented in the burials at the summer children's camps of the GorONO and the Gremyachiy Ruchei. In the grave pit of the GorONO burial, perpendicular to the river, as the researcher notes, the anatomical order of the female skeleton was disturbed; relatively correct anatomical order of the upper bones of the postcranial skeleton was preserved. The bones of the legs were placed over the corpus bones. The skull was in the lower, southern part of the grave (Glusskaia, 1963a: 29). Among the grave goods, there were ornaments made of the canine teeth of wild boar pig, wolf and bear, also of the bones, stones, river shells and pearls, as well as adzes, scraper-like tools, knife, scrapers, and needle case (Glusskaia, 1963a: 31). In two graves of the Gremyachiy Ruchei, along the east - west line, presumably along the river, the anatomical order of the bones was also disturbed and the burials were mostly destroyed. The funeral equipment included tools (fragment of the adze, fragments of arrowheads, needle case, bone awls and borers, etc.) and jewelleries, including a bracelet (?) made of the beaver incisors, animal teeth pendants (polar fox, maral, bear), bone plates with the images of birds, mother-of-pearl beads, as well as made of bone

of the $5^{\text {th }}$ burial given here (Savenkov, 2001: 89).
porTable art depicting fish, moose and birds (Glusskaia, 1963b: 40). There no another general features of the Udachny-14 burial with other well-known burials in the Krasnoyarsk region noted.

The analysis of the Neolithic burials from different regions of Siberia allowed I.T. Savenkov to outline, and later A.P. Okladnikov, to identify the local features of the Krasnoyarsk burials. These included: the absence of stone masonry, the bone needle-shaped points among the tools, which have cuts instead of ears, a significant number of pearlescent beads, ceramic vessels, partially resembling egg-shaped pots and zonal ornament of the Afanasyevo culture.

Comparing the burials on the ritual and equipment, A.P. Okladnikov divided them into two groups. The early one - the Serovo - included the burials with the figures of moose and inset tools at the Bazaikha (graves 5 and 6) and the burial in Bateny (the Minusinsk Hollow). The last group, in his opinion, represented by the burials 1, 2 of Afontova Gora, the destroyed burial (?) on K. Marksa street in the city of Krasnoyarsk and burials 1 and 2 near Perevoznaya site. They are characterized by soil graves without masonry, partial filling with red ochre, ceramic vessel, jewelleries small white beads and mother-of-pearl beads, moose incisors pendants, pear-shaped pendants made from maral canines, and sculptural objects (including awl-shaped human figures), bone plates (armours). For this group, he pointed out the similarity of a number of features with the burials from the Baikal region and the lower reaches of the Angara ("the later Kitoy, or, even closer, the early Eneolithic, such as the Anosovo burial") (Okladnikov, 1949: 12-13; Okladnikov, 1957).

Taking into account some further discoveries, the two-term scheme for the development of Neolithic burial complexes proposed by A.P. Okladnikov requires clarification. So, the visions of the groups' age have changed. The "late" burials, judging by the Ust'-Belaya type vessels found in burial № 4 on Afontova Gora, can be dated to the Middle Neolithic (Makarov, 2005; Savenkova, Makarov, 2018). The Serovo funeral tradition, according to the overall ${ }^{14} \mathrm{C}$ dating of burials, is currently cor- 
related with the Late Neolithic (5571 \pm 88 $4597 \pm 76$ cal BP) (Bazaliiskii, 2012; Weber at all., 2016). Thus, "the early" burial group considered by A. P. Okladnikov should be dated as well. It can contain (except for the number 5 and 6 of the "Bor" urotshitsche, familiar to the author) the burials of the Gremyachy Ruchei, at the GorONO dachas and of the Udachny-14 site, which were discovered later. Their similarity was reasoned by a deliberate disturbance of the anatomical order of the buried individual and the presence of an above- or near-grave fire. Different sets of accompanying equipment were probably linked to the age and gender of the buried. However, it should be noted that all of them necessarily have jewellery made of animal teeth, of bone in the form of pear-shaped pendants (simulating the teeth), of pearls and stones.

It is possible to use the obtained anthropological data in searching for the analogies to the materials of the Udachny-14. Due to the observations unicity, it is not possible to carry out a statistical intergroup comparison of the dental non-metric features, but it makes sense to compare them with the known Neolithic samples. Unfortunately, to date, the materials drawn for the comparison from the Neolithic burials around the city of Krasnoyarsk have not been examined according to the dental non-metric programme. There were only the series of the East European Plain of pit-comb ceramics culture (Fomino, Karavaikha) (Zubova, 2016: 143-144) and of the Dnieper-Donetsk cultural community (Yasinovka, Nikolskoye, Vovnigi-1) (At al.) available for the comparison. There are the data on samples from the forest-steppe foothills of Altai (Solonetsy 5, Ust'-Isha), the Kuznetsk Basin (Lebedi, Vas'kovo) and the Barabinskaya forest-steppe (Sopka-2/1, Protoka, Korchugan) (Chikisheva, 2012). The population of the Eastern Siberia is represented by the samples from the Baikal region on the Kitoy (Fofonovsky burial site) (Leibova, Zhambaltarova, 2016), the Serovo (Manzurka, Verkholensk, Vorobyevo, the mouth of the Belaya river) and the Glazkovskaya burial traditions (Obkhoy, Makarovo, the mouth of the Belaya river, Fofanovo, Nikolskoye, Buret' -
Sukhaya Pad ', Shivera), as well as a series of the Ymyyakhtak Late Neolithic culture of Yakutia (Pomazkino, Kamenka-2, Matta, Dering-Yuryakh, Kerdyugen, Vilyuiskoye shosse) (Zubova, 2018). A short anthropological sample from the Sosnovy Mys burial site on the territory of the Northern Angara region was also used for the analysis (Privalikhin, 1998; unpublished copyright data).

In the pit-comb ceramics culture groups and in the Dnieper-Donets cultural community of the East European Plain, the marks of the eastern stem are almost absent (Zubova, 2016: 143-144). The Neolithic population of the Altai forest-steppe foothills is characterized by both a combination of high frequencies of individual features and the "eastern" and "western" features (Solontsy 5), and the predominance of the "eastern" indicators (Ust'-Isha). A mosaic mix of the "eastern" and "western" dental markers was also attributed to the population of the Kuznetsk Basin. The dental non-metric data of the Barabinskaya forest-steppe is characterized by the strong "eastern" features in the complex (Chikisheva, 2012: 51-53).

The Eastern Siberia data merges by the overwhelming majority of the "eastern" markers: increased frequencies of shovel-shaped incisors, six-cusp forms first lower molars, lower frequencies of four-cusp second molars (Leibova, Zhambaltarova, 2016; Zubova, 2018). At the same time, in the series of the Baikal Region Neolithic, there are increased frequencies of the Carabelli cusp (the Kitoy and the Serovo burial traditions), as well as great number (the Kitoy burial tradition) and high frequencies of tami (the Glazkovskaya and the Serovo burial traditions). The Yakutia Neolithic is characterized by high frequencies of deflecting wrinkle. The greatest similarity of the individual from the Udachny-14 is with the short Neolithic series from the Northern Angara region. It was in this small group that a similar combination of signs of the "eastern" (shovel-shaped incisors, deflecting wrinkle), "western" (Carabelli cusp, fourcusp second lower molars) stems and archaic markers (finger-like crests on the central incisors and distal ridge on the premolars) were 
noted (unpublished copyright data). Relying on the information above, the population of the Krasnoyarsk region in the Late Neolithic period was likely to have more ties with the groups from the Northern Angara region than with the population from the Baikal Region (the Southern Angara Region, the Baikal and the Upper Lena).

Such similarity of the examined anthropological materials of the Sosnovy Mys burial site (the 1974-1986 excavations) and the Udachny-14 burial site has not been confirmed by the archaeological data. Reliably attributed to the Late Neolithic, burial № 9 demonstrates poor relations in the ritual and accompanying burial tools with the Krasnoyarsk ones (Privalikhin, Drozdov, Makulov, 2013: 46-54). There are some similarities revealed with the Neolithic burials, discovered at the Sosnovy Mys during the 2011 rescue operations, in the funeral rite: the absence of masonry in some graves, the elongated position of the bones on the back, traces of secondary (?) practices and the use of ochre. The accompanying tools also demonstrate a set typical for the Krasnoyarsk group: the bone fragments of needles and needle case, pendants made of musk deer canines, maral, split boar canines (Savel'ev, Timoshchenko, Badmaev, 2011: 460-462). The comparative studies with other Neolithic burial complexes of the Northern Angara Region are almost impossible due to their small number and lack of cultural-chronological systematization. The published materials indicate only single attributes, e.g. "funeral" fire (Zaika, 2009), various secondary funerary practices (Petrova and etc, 1976; Garkusha, Marchen- ko, Grishin, 2013; Derevianko and etc, 2015: 510-511); inclusion of mineral dyes (Derevianko and etc, 2015: 510). Thus, a complete solution to the question on what the Northern Angara region's population contributed to the funerary traditions of the Late Neolithic, represented in the Krasnoyarsk region, is still impossible.

\section{Conclusion}

The Udachny-14 burial site shows similarities with a number of other well-known burials (burial № 5 and № 6 of the "Bor" urotshistshe, at the Gremyachy Ruchei and at the dachas of the GorONO), excavated in Krasnoyarsk and its outskirts and considered as a separate group. Basing on the ${ }^{14} \mathrm{C}$ date and the analogies in the Late Neolithic burial traditions of Angara and Baikal regions, the age of these burials is preliminary identified as the Late Neolithic. They are characterized by: the location of grave pits mainly along the river, the presence of over- or near-grave fire, post-mortem manipulations with the body or bones, ochre traces, jewellery made of animal teeth, and also stone tools and bone pieces. A wide range of issues arising in terms of this burial group requires further research. In particular, the search for inter-regional analogies and models of cultural interaction in the western (with the territory of the Upper Ob') and the eastern (Kansk forest-steppe, the Angara-Baikal region) directions seems to be a priority task. However, now we can confidently assume their connection with the circle of funerary traditions of the late Neolithic of the Northern Angara region.

\section{References}

Alekseev, V.P. (1966). Osteometriia. Metodika antropologicheskikh issledovanii [Osteometry. Methods of the anthropological research]. Moscow, Science, $251 \mathrm{p}$.

Alekseev, V.P. (1983). Novaia paleoantropologicheskaia nakhodka eneoliticheskogo vremeni pod Krasnoiarskom [New paleoanthropological finding of the Eneolithic time near the Krasnoiarsk]. In Sovetskaia etnografiia [Soviet Ethnography], 4, 102-105.

Auerbakh, N.K. (1929). Doistoricheskoe proshloe prieniseiskogo kraia. Chast' 1: kamennyi period [Prehistory of the Yenisei area. Part 1: the Stone Age]. Krasnoiarsk, Central Siberian State Geographical Society, 19 p.

Bass, W.M. (1987). Human osteology. A laboratory and field manual. Columbia, Missouri Archaeological Society, 327 p. 
Bazaliiskii, V.I. (2012). Pogrebal'nye kompleksy epokhi pozdnego mezolita - neolita Baikalskoi Sibiri: traditsii pogrebenii, pogrebalnyi vozrast [Burial complexes of the Late Mesolithic - Neolithic Baikal Siberia: burial traditions and age]. In Izvestiia Laboratorii drevnikh tekhnologii [Bulletin of the Laboratory of Prehistoric Technologies], 1(9), 43-101.

Chikisheva, T.A. (2012). Dinamika antropologicheskoi differentsiatsii naseleniia iuga Zapadnoi Sibiri epokhi neolita - rannego zheleza [Dynamics of anthropological differentiation of the population of the south of Western Siberia in the Neolithic - Early Iron Age]. Novosibirsk, Siberian Branch of the Russian Academy of Sciences, $468 \mathrm{p}$.

Derevianko, A.P., Tsybankov, A.A., Postnov, A.V., Slavinskii, V.S., Vybornov, A.V., Zol'nikov, I.D., Deev, E.V., Prisekailo, A.A., Markovskii, G.I., Dudko, A.A. (2015). Boguchanskaia arkheologicheskaia ekspeditsiia: ochrek polevykh issledovanii (2007-2012 gody) [Boguchany archeological expedition: essay of the field research (2007-2012)]. Novosibirsk, Siberian Branch of the Russian Academy of Sciences, $564 \mathrm{p}$.

Dudarek, S.P., Lokhov, D.N., Leibova, N.A. (2015). Novyi ob'ekt arkheologicheskogo naslediia Romashka v Severnom Priangar'e [The new archeological site Romashka in Northern Angara region]. In Izvestiia Laboratorii drevnikh tekhnologii [Bulletin of the Laboratory of Prehistoric Technologies], 14, 49-66.

Duday, H. (2009). The Archaeology of the Dead: Lectures in Archaeothanatology. Translated by Anna Maria Cipriani and John Pearce. Oxford, Oxford University Press, 158 p.

Garkusha, Iu.N., Marchenko, Zh.V., Grishin, A.E. (2013). Pogrebeniia na stoianke Pashina (Severnoe Priangar'e): problemy opredeleniia khronologicheskoi i kulturnoi prinadlezhnosti [Burials from the site Pashina (Northern Angara region): problems of determining chronology and culture]. In Vestnik Novosibirskogo Gosudarstvennogo Universiteta [Journal of Novosibirsk State University], 12(7), 186-197.

Glusskaia, Z.K. (1963b). Novoe v iskusstve neolita na Enisee [The new in the art of the Neolithic on the Yenisei River]. In Materialy $i$ issledovaniia po arkheologii, etnografii i istorii Krasnoiarskogo kraia [Materials and research of the archeology, ethnography and history of the Krasnoiarsk Krai], 39-48.

Glusskaia, Z.K. (1963a). Zhenshchina negroidnogo tipa v neolite pod Krasnoiarskom [Negroid woman in the Neolithic near the Krasnoiarsk]. In Materialy i issledovaniia po arkheologii, etnografii i istorii Krasnoiarskogo kraia [Materials and research of the archeology, ethnography and history of the KrasnoiarskKrai], 29-37.

Gurulev, D.A., Biriuleva, K.V. (2018). Kamennaia industriia ust-bel'skogo kompleksa stoianki Udachnyi-14 (poitogamrabot $2015 \mathrm{~g}$.) [Lithic industry of the Ust'-Belskaia complex of the Udachny-14 site (according to the results of the work in 2015)]. In Chelovek i sever: Antropologiia, arkheologiia i ekologiia: Materialy vserossiiskoi nauchnoi konferentsii [Man and the North: Anthropology, Archeology and Ecology: Materials of the All-Russian Scientific Conference], Tyumen, 4, 59-62.

Khlobystin, L.P. (1996). Vostochnaia Sibir' i DalniiVostok [The Eastern Siberia and the Far East]. In Arkheologiia. Neolit Severnoi Evrazii [Archeology. The Neolithic of the North Eurasia], 270-330.

Leibova, N.A., Zhambaltarova, E.D. (2016). Odontologicheskaia kharakteristika naseleniia Iugo-Vostochnogo Pribaikal'ia epokhi neolita i rannei bronzy [Odontological characteristics of the population of the South-Eastern Baikal region in the Neolithic and Early Bronze Age]. In Tezisy XVII Mezhdunarodnoi Zapadnosibirskoi arkheologo-etnograficheskoi konferentsii: "Vostok i Zapad: problemy sinkhronizatsii etnokulturnykh vzaimodeistvii" [Abstracts of the XVII International West Siberian Archeological and Ethnographic Conference: "East and West: Problems of Synchronization of Ethnocultural Interactions"]. Tomsk, available at: http://zsaek.tsu.ru/sites/default/files/webform/Лейбова_Томск_тезисы_испр3.pdf

Makarov, N.P. (2005). Khronologiia i periodizatsiia epokhi neolita i bronzy krasnoiarskoi lesostepi [Chronology and periodization of the Neolithic and Bronze Age of the Krasnoiarsk forest-steppe zone]. In Izvestiia Laboratorii drevnikh tekhnologii [Bulletin of the Laboratory of Prehistoric Technologies], 3, 149-170.

Okladnikov, A.P. (1949). Neoliticheskie pogrebeniia na Afontovai gore [Neolithic burials from the Afontova Gora site]. In Kratkie soobshcheniia Instituta istorii materialnoi kultury [Brief reports of the Institute of the History of the Material Culture], XXV, 7-13. 
Okladnikov, A.P. (1950). Neolit i bronzovyivek Pribaikal'ia. Ch. 1, 2 [Neolithic and Bronze Age of the Baikal Region. Part 1, 2]. Moscow, Leningrad, Academy of Sciences of the USSR, 411 p.

Okladnikov, A.P. (1957). Iz istorii etnichesk i khkulturnykh sviazei neoliticheskikh plemen Srednego Eniseia (k voprosu o proiskhozhdenii samodiiskikh plemen) [The history of the ethnic cultural ties of the Neolithic tribes of the Middle Yenisei (to the question of the genesis of the Samoyedic tribes)]. In Sovetskaia arkheologiia [Soviet archeology], 1, 26-55.

Okladnikov, A.P. (1976). Neoliticheskie pamiatniki Nizhnei Angary (ot Serovo do Bratska) [Neolithic sites of the Low Angara Region (from Serovo to Bratsk)]. Novosibirsk, Science, 326 p.

Peredolskii, V.V. (1896). Po reke Eniseiu i ego pritokam [On the Yenisei River and its tributaries]. In Izvestiia imperatorskogo Russkogo geograficheskogo obshchestva [Bulletin of the Royal Russian Geographical Society], XXXII, 210-214.

Petrov, A.I. (1994). Neolit i ranniaia bronza [Neolithic and Early Bronze Age]. In Ochreki kulturogeneza narodov Zapadnoi Sibiri. Mir realnyi i potustoronnii [Essays of the cultural genesis of the peoples from Western Siberia. The world is real and beyond death], 2, 34-63.

Petrova, N.A., Smotrova, V.I., Smotrova, G.I., Drozdov, N.I., Larchenko, S.I. (1976). Raskopki drevnego mogil'nika na Srednei Angare [Excavations of the ancient burials from the Middle Angara region]. In AO 1975 g. [Archaeological Discoveries in 1975], 272-273.

Privalikhin, V.I. (1998). Sosnovyi Mys - 2 - novyi raznovremennyi mogil'nik Severnogo Priangaria [Sosnovyi Mys-2 a new burials of different time of the Northern Angara region]. In Sibirskii mezhmuzeinyi sbornik [Siberian Intermuseum Collection of Articles], 72-87.

Privalikhin, V.I., Drozdov, N.I., Makulov, V.I. (2013). Issledovaniia neoliticheskikh pogrebenii v Severnom Priangar'e (zona zatopleniia Boguchanskoi GES) [Researching of Neolithic burials in the Northern Angara Region (flooded area of the Boguchanskaia HPP)]. In Arkheologicheskie issledovaniia drevnostei Nizhnei Angary isopredelnykh territorii [Archaeological research of the antiquities of the Lower Angara Region and adjacent territories], 42-56.

Savenkov, I.T. (1886). K razvedochnym materialam po arkheologii srednego techeniia Eniseia [To exploration materials of the archeology of the Middle Yenisey]. In Izvestiia Vostochno-Sibirskogo otdela Russkogo geograficheskogo obshchestva [Bulletin of the East-Siberian Department of the Russian Geographical Society], XVII(3-4), 26-101.

Savenkov, I.T. (2001). Ob ostankakh epokhi neolita naidennykh v Eniseiskoi gubernii (Vostochnaia Sibir'), na beregu Eniseia okolo ust'evrek Bazaikhii Chadobets (predvaritelnoe soobshchenie) [About Neolithic of the Yenisei province (Eastern Siberia), on the bank of the Yenisey, near the mouths of the Bazaikha and Chadobets rivers (preliminary report)]. In Drevnosti Prieniseiskoi Sibiri [Antiquities Yenisey Siberia], 2, 87-90.

Savenkova, T.M., Makarov, N.P. (2018). Antropologiia i arkheologiia pogrebenii neolita i rannei bronzy Krasnoiarskoi lesostepi [Anthropology and archeology of the Neolithic and the Early Bronze burials of the Krasnoiarsk forest-steppe zone]. In Materialy IX Mezhdunarodnoi nauchnoi konferentsii "Drevnie kul'tury Mongolii, Baikal'skoi Sibirii Severnogo Kitaia" [Reports IX International Scientific Conference "Ancient cultures of Mongolia, Baikal Siberia and Northern China"]. Ulan-Ude, $1,158-162$.

Savel'ev, N.A., Timoshchenko, A.A., Badmaev, D.A. (2011). Spasatel'nye raboty piatogo Ust'-Ilimskogo otriada na pamiatnike Sosnovyi Mys v 2011 godu [Rescue excavations of the fifth Ust'-Ilim detachment of the Sosnovyi Mys site in 2011]. In Problemy arkheologii, etnografii, antropologii Sibiri i sopredelnykh territorii [Problems of archeology, ethnography, anthropology of Siberia and adjacent territories], XVII, 457-462.

Titova, Iu.A., Biriuleva K.V., Mandryka, P.V. Stoianka Udachnyi-14 v okrestnostiakh Krasnoiarska (nekotorye itogi polevykh rabot) [Site Udachnyi-14 near the Krasnoyarsk (preliminary report on the results of works 2014-2015)]. In Drevnosti Prieniseiskoi Sibiri [Antiquities Yenisey Siberia], VIII, 147-153.

Timoshchenko, A.A., Savel'ev, N.A., Bobrov, V.V. (2016). Kazachinskaia kultura neolita krasnoiarsko-kanskoi lesostepi (po materialam mnogosloinogo poseleniia Kazachka) [Kazachka Neolithic culture of 
theKrasnoiarsk-Kansk forest-steppe zone (based on materials of the multi-layered settlement Kazachka)]. In Materialy VII Mezhdunarodnoi nauchnoi konferentsii "Drevniekul'tury Mongolii, Baikal'skoi Sibirii SevernogoKitaia" [Reports VII International Scientific Conference "Ancient cultures of Mongolia, Baikal Siberia and Northern China"']. Krasnoiarsk, 1, 99-07.

Ubelaker, D.H. (1978). Human skeletal remains: Excavation, analysis, interpretation. Chicago, Aldine, $312 \mathrm{p}$.

Vdovin, A.S., Makarov, N.P. (2016). Afontova gora. Materialy epokhi neolita i rannei bronzy [Afontova Gora site. Materials of the Neolithic and the Early Bronze Age]. In Esse guamvideri: k 80-letiiu Germana Ivanovicha Medvedeva [Esseguamvideri: to the 80th anniversary of German Ivanovich Medvedev], 339-348.

Weber, A.W., Schulting, R.J., Ramsey, C.B., Bazaliiskii, V.I., Goriunova, O.I., Berdnikova, N.E. (2016). Chronology of middle Holocene hunteregatherers in the Cis-Baikal region of Siberia: Corrections based on examination of the freshwater reservoir effect. In Quaternary International (419), 74-98. DOI: https:/doi. org/10.1016/j.quaint.2015.12.003

Zaika, A.L. (2009). Neoliticheskoe pogrebenie v ust'e r. Kamenkina Nizhnei Angare [The Neolithic burial at the mouth of the river Kamenka in the Lower Angara region]. In Izvestiia Laboratorii drevnikh tekhnologii [Bulletin of the Laboratory of Prehistoric Technologies], 7, 60-72.

Zaitseva, O.V., Razhev, D.I. (2007). Vozmozhnosti rekonstruktsii osobennostei pervonachal'nogo razmeshcheniia tela $\mathrm{v}$ pogrebeniiakh po obriadu ingumatsii [Possibilities of reconstruction of the specialties of the initial body placement in the inhumation burials]. In Vestnik Tomskogo gosudarstvennogo universiteta [Tomsk State University Journal], 302, 84-89.

Zubov, A.A. (1968). Odontologiia. Metodika antropologicheskikh issledovanii [Odontology.Methods of the anthropological research]. Moscow, Science, $199 \mathrm{p}$.

Zubov, A.A. (2006). Metodicheskoe posobie po antropologicheskomu analizu odontologicheskikh materialov [Methodological manual of the anthropological analysis of odontological materials]. Moscow, Ethno-Online, $72 \mathrm{p}$.

Zubova, A.V. (2013). Predvaritelnye rezultaty izucheniia arkhaichnoi sostav liaiushchei odontologicheskikh kompleksov naseleniia Evrazii epokhi neolita [Preliminary results of studying the archaic component of the odontological complexes of the Eurasia population in the Neolithic]. In Vestnik antropologii [Journal of Antropology], 4(26), 107-127.

Zubova, A.V. (2016). Sostav mezoliticheskogo i neoliticheskogo naseleniia lesostepnoi polosy Vostochno-Evropeiskoi ravniny po odontologicheskim materialam [Composition of the Mesolithic and Neolithic population of the forest-steppe zone of the East European Plain according to the odontological materials]. In Arkheologiia, etnografiia i antropologiia Evrazii [Archaeology, Ethnology \& Anthropology of Eurasia], 44(3), 139-149. DOI: 10.17746/1563-0110.2016.44.3.139-149

Zubova, A.V. (2018). Neoliticheskoe naselenie Iuzhnogo Primor'ia i ego rol' v formirovanii korennogo naseleniia Dalnego Vostoka (po odontologicheskim dannym iz mogilnika Boismana-2) [Neolithic population of the Southern Primorye and its affinities with the indigenous population of the Far East (based on dental non-metric traits from the Boysman-2 burial ground sample)]. In Camera praehistorica, 1, 117-128. DOI: $10.33291 / 26583828.2018-(1)-7$ 


\title{
Неолитическое погребение ребенка из Красноярского района
}

\author{
П.В. Мандрыка ${ }^{a}$ О.Е. Пошехоноваб ${ }^{6}$ К.В. Бирюлева ${ }^{a}$, \\ Л.А. Максимовича , А.В. Слепцова ${ }^{6}$, Д.А. Гурулёв \\ ${ }^{a}$ Сибирский федеральный университет \\ Российская Федерачия, Красноярск \\ ${ }^{\circ} Ф И Ц$ ТюмНЦ СО РАН \\ Институт проблем освоения Севера \\ Российская Федерация, Тюмень
}

\begin{abstract}
Аннотация. Статья посвящена анализу материалов неолитического погребения, обнаруженного на стоянке Удачный-14 в г. Красноярске. Скелет ребенка 9-10 лет располагался головой на юго-запад параллельно реке (против течения). Над могилой отмечен прокал, в котором обнаружена пяточная кость благородного оленя. Между черепом и костями таза зафиксированы два параллельно лежащих резца бобра, которые могли относиться к деталям одежды либо к украшению. Возле левых плюсневых костей найден кусок охры. Практически все кости ног захороненного индивида находились в анатомическом порядке и были вытянуты вдоль длинной оси захоронения. Кости туловища, плечевого пояса и головы были значительно перемещены. Расположение костей дает основание предполагать, что могила была потревожена через небольшой промежуток времени после похорон. Одонтологическое обследование останков показало сочетание в строении зубной системы «восточных» и «западных» признаков с преобладанием первых. Наибольшее одонтологическое сходство погребенного фиксируется с небольшой неолитической серией из Северного Приангарья, что частично коррелирует с археологическими данными. На основании полученной $14 \mathrm{C}$ даты и стратиграфического положения захоронение датировано поздним неолитом (конец IV тыс. до н.э.). Среди немногочисленных памятников региона оно находит аналогии в материалах некрополей из урочища «Бор» в устье р. Базаихи, у летних детских дач ГорОНО и Гремячего ручья. Для них характерны грунтовый характер погребений, расположение могильных ям преимущественно вдоль реки, посмертные манипуляции с телом умерших, наличие следов надмогильного или околомогильного костра, использование в качестве сопроводительного инвентаря украшений из зубов и костей животных.
\end{abstract}

Ключевые слова: Средний Енисей, Красноярский район, стоянка Удачный-14, поздний неолит, антропологическая характеристика, одонтологическое обследование, погребальный обряд, посмертные манипуляции с телом.

Работа выполнена в рамках государственного задания. Проект № AAAA-A17-117050400143-4.

Научная специальность: 07.00.00 — исторические науки и археология. 